
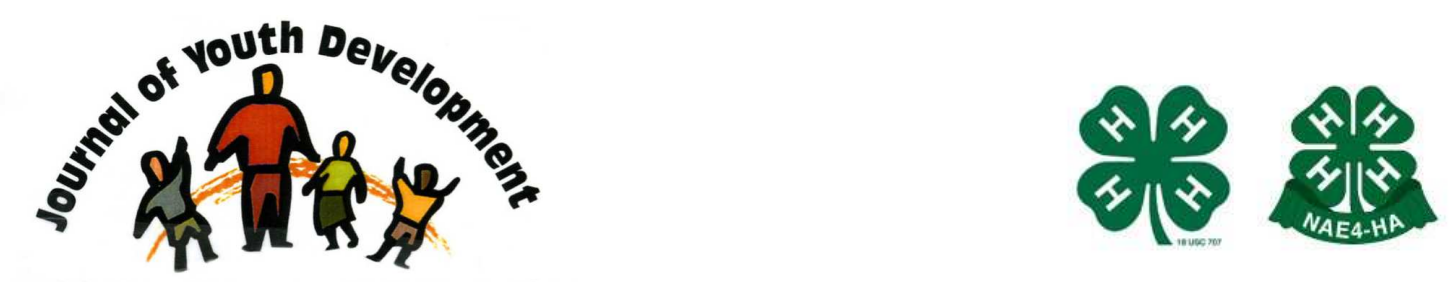

Bridging Research \& Practice

\title{
The Use of Expressive Therapies and Social Support with Youth in Foster Care: The Performing Arts Troupe
}

\author{
Audra Holmes Greene \\ Casey Family Services \\ Bridgeport, CT \\ aholmesgreene@caseyfamilyservices.org \\ Linda Goldenberg \\ Casey Family Services \\ Bridgeport, CT \\ lgoldenberg@caseyfamilyservices.org \\ Madelyn Freundlich \\ Excal Consulting Partners, LLC \\ New York, NY \\ mdf@excalconsulting.com
}




\title{
JOURNAL OF YOUTH DEVELOPMENT \\ bridging research and practice

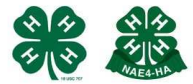

Volume 4, Number 1, Spring 2009

Article 090401FA005

\section{The Use of Expressive Therapies and Social Support with Youth in Foster Care: The Performing Arts Troupe}

\author{
Audra Holmes Greene and Linda Goldenberg \\ Casey Family Services \\ Madelyn Freundlich \\ Excal Consulting Partners, LLC
}

\begin{abstract}
The Performing Arts Troupe is a program that provides youth in foster care and youth from low income neighborhoods with expressive therapies and social support. The program is designed to assist youth in addressing the effects of trauma and developing competencies as they prepare to transition to adulthood. The article discusses the literature base for the program, the program activities and describes the impact of the program on youth through preliminary evaluations and case studies. The program offers an innovative combination of expressive therapies and social supports that has effectively met the needs of vulnerable youth.
\end{abstract}

\section{Introduction}

Over the past decade, attention has increasingly focused on the needs of vulnerable youth, including youth in foster care. There has been a growing understanding of the developmental needs of youth who have been maltreated or experienced family- or community-based violence (Bussiere, Pokempner, \& Troia, 2005; Cook, Spinazzola, Ford, Lanktree, C., et al., 2005). There also has been a recognition of the limited opportunities that vulnerable youth may have to develop competencies that will serve them well through adolescence and into adulthood (Arnett, 2000, 2001). New approaches have been proposed to meet the psychosocial and life skills needs of vulnerable youth who have not been well served by traditional programs (Massinga \& Pecora, 2004).

The Performing Arts Troupe is a program developed by Casey Family Services, the direct service agency of the Annie E. Casey Foundation, in its Bridgeport, Connecticut Division. The program was designed to meet the developmental, psychosocial and life skills needs of youth in foster 
care and other youth in the Bridgeport community. Building on research and practice literature that suggests the effectiveness of expressive therapies and social support in promoting positive outcomes for vulnerable youth, the Performing Arts Troupe provides youth with opportunities to develop and implement a range of youth-driven expressive art activities within a supportive environment.

This article describes the literature that has guided the development of the program model and implementation of the program. It then discusses the history of the program and its current structure and activities. The article reviews the results of preliminary evaluations with youth participants and provides short descriptions of the experiences of five youth in the Performing Arts Troupe program. It concludes with a discussion of factors associated with the replication of this program in other settings.

\section{Literature Review}

The Performing Arts Troupe program is grounded in the growing body of knowledge about the effects of urban poverty on youth and the impact of trauma on youth who have experienced abuse and neglect and who subsequently enter foster care. The program is shaped by research that has demonstrated the effectiveness of interventions that promote youth resiliency, provide healing from trauma through the use of social support and expressive therapies, and support youth in developing competencies that prepare them to transition to adulthood.

\section{Urban Youth and Hopelessness}

The ethnographic literature indicates that adolescents who live in low-income, urban neighborhoods are particularly susceptible to hopelessness and its consequences (Bolland, 2003). Joiner and Wagner (1995, p. 778) define hopelessness as "an expectation that highly desired outcomes will not occur or that negative ones will occur... and that nothing is going to change things for the better." Children who live in impoverished neighborhoods "may despairingly conclude that... they have neither the resources nor the likelihood of achieving lasting or socially approved outcomes" (Lorion \& Saltzman, 1993, p. 56). Studies have contributed to a fuller understanding of the consequences of hopelessness for youth in inner city neighborhoods. Bolland (2003), for example, studied the experiences of 2,468 adolescents in 12 low-income neighborhoods in an urban community, and found that feelings of hopelessness were associated with multiple domains of risk behavior, including violence, substance use, premature sexual activity, and accidental injury.

The literature suggests that hopelessness can be viewed as a cognitive style (Abramson, Metalsky, \& Alloy, 1989; Abramson, Seligman, \& Teasdale, 1978; Allen \& Tarnowski, 1989) and, as such, can be addressed through individual and group therapeutic interventions. Studies indicate that adolescents can overcome the limitations of hopelessness with the help of interventions that assist them to better understand their cognitive-affective responses to adversity and that provide them with the ability to take advantage of positive life opportunities (Boland, 2003). Specifically, youth's experiences of hopelessness as well as helplessness can be effectively addressed through skill-building and efficacy-enhancing interventions (Boland, 2003). These interventions, which have both therapeutic and competency-building goals, are integral to Casey's Performing Arts Troupe program.

\section{The Impact of Trauma on Youth in Foster Care}

The recognition of the association between maltreatment and post traumatic stress disorder (PTSD) (Buckner, Beardslee, \& Bassuk, 2004; Carrion, Weems, Ray, \& Reiss, 2002) informs the 
design of the Performing Arts Troupe. Many youth who enter foster care have experienced significant levels of abuse or neglect, and as a result, struggle with the impact of trauma and loss (Henry, 2005; Kimball \& Golding, 2004). Issues of loss, identity, attachment, safety and a sense of belonging are often paramount (Henry, 2005). Research indicates that chronic exposure to trauma may affect children's and youth's cognitive, physiological, social, emotional and behavioral development (Anderson, 2005). Because they often redirect resources that would be devoted to growth and development to survival, maltreated children and youth may be at risk for poorer developmental outcomes and challenges in emotional regulation (Cook, Blaustein, Spinazzola, \& van der Kolk, 2003). Socially, they may isolate themselves from others, including peers (Armsworth \& Holaday, 1993).

Based on research findings that indicate that trauma predicts increased emotional distress during adolescence (Garber, Keiley, Martin, 2002; Ge, Lorenz, Conger, \& Elder, 1994), the Performing Arts Troupe focuses on the developmental tasks of adolescence, including the development of coping skills and competencies that will serve them as they transition to adulthood and the cognitive processing of complex and abstract ideas. Youth who have experienced chronic trauma may have poor language and communication skills and learning disabilities (Armsworth \& Holaday, 1993), difficulties which, in turn, may affect youth's functioning in social contexts (Armsworth \& Holaday, 1993) and their ability to become involved with others and learn from past experiences (Anderson, 2005). An understanding of the impact of chronic trauma on youth's cognitive processing, social functioning and ability to relate effectively to others provides a critical foundation for the development and implementation of the Performing Arts Troupe.

\section{Interventions to Promote Resilience}

Resilience is the focus of much of the literature that describes effective interventions with youth who face the challenges associated with poor, urban environments and youth who have experienced maltreatment. Resilience has been defined as "the process of, capacity for, or outcome of successful adaptation despite challenging or threatening circumstances" (Masten, Best, \& Garmezy, 1990, p. 426). Research suggests that many youth, despite experiences of complex trauma, demonstrate resilience and function competently and effectively across many domains (National Child Traumatic Stress Network, 2003).

The research has identified a number of factors as critical in promoting resilience, each of which is relevant to the design of the Performing Arts Troupe program. Studies indicate that the following factors are among the most important in promoting resilience:

- positive attachment and connections to emotionally supportive adults within the family or community,

- development of cognitive and self-regulating abilities, positive beliefs about oneself, and

- motivation to act effectively in one's environment (Luthar, Cicchetti, \& Becker, 2000; Masten, 2001; Werner \& Smith, 1992; Wyman, Sandler, Wolchik, \& Nelson, 2000).

The Performing Arts Troupe activities integrate each of these factors in order to promote youth's resilience in relation to their current life circumstances, and these activities provide them with opportunities to develop the core competencies needed as they transition from adolescence to adulthood.

The Performing Arts Troupe is a program developed by Casey Family Services, the direct service agency of the Annie E. Casey Foundation, in its Bridgeport, Connecticut Division. The program was designed to meet the developmental, psychosocial and life skills needs of youth in foster 
care and other youth in the Bridgeport community. Building on research and practice literature that suggests the effectiveness of expressive therapies and social support in promoting positive outcomes for vulnerable youth, the Performing Arts Troupe provides youth with opportunities to develop and implement a range of youth-driven expressive art activities within a supportive environment.

This article describes the literature that has guided the development of the program model and implementation of the program. It then discusses the history of the program and its current structure and activities. The article reviews the results of preliminary evaluations with youth participants and provides short descriptions of the experiences of five youth in the Performing Arts Troupe program. It concludes with a discussion of factors associated with the replication of this program in other settings.

\section{Expressive Therapies}

Research supports a range of expressive interventions that promote positive outcomes for youth who have experienced chronic trauma. Non-verbal therapeutic approaches, which constitute the heart of the Performing Arts Troupe, have been found to be particularly effective with children and youth who have experienced significant maltreatment and who exhibit attachment difficulties (Klorer, 2005). Studies suggest that creative therapies, including art and writing, are effective in helping individuals heal from traumatic experiences (Kaduson \& Schaefer, 2001; Pennefaker, Colder, \& Sharp, 1990; Yamaguchi, 1997). There also is evidence that writing therapy reduces stress, improves health, increases positive affect, and promotes coping skills (Harber \& Pennebaker, 1992; Pennebaker \& Francis, 1996; Smythe, 1998).

Art therapy has long been used with individuals who have experienced trauma (Rubin, 1999). Art offers specific advantages as it does not require literacy or verbal fluency. Art allows the individual to communicate emotion and tell a story, and it stimulates verbal expression (Pizarro, 2004). Studies have shown that creative expression through art contributes to a positive change in self-esteem (Reynolds, Nabors, \& Quinlan, 2000). In particular, visual art therapies have been found to be effective in the multidimensional treatment of PTSD (Avrahami, 2006). Consistent with work that has demonstrated the positive effects of social support, drumming groups have been found to enhance health through their effects on social support and social networks (Winkleman, 2003). Although drumming has not been the subject of empirical research, practitioners find that it can be effective in addressing some of the effects of emotional trauma; alleviating self-centeredness, isolation, and alienation; and creating a sense of connectedness to self and others (Winkleman, 2003).

\section{The Performing Arts Troupe}

\section{The Historical Roots of the Program}

The Performing Arts Troupe had its beginnings in 1999 when Casey Family Services offered youth in foster care an opportunity to participate in a choir directed by two community musicians. The program later added percussion instruments and a dance component. Adults initially designed and directed the activities, but as youth continued to participate in the program, they began to express their need for greater input. In September 2005, participating youth made clear to Casey Family Services that they wished to "own" the program and make decisions about the activities that would be offered.

This pivotal development changed the nature and course of the Performing Arts Troupe. At that point, youth began to take leadership roles in decisions regarding the types of activities that the 
program would offer. When youth voiced interest in drumming and other expressions of their African American cultural heritage, Casey Family Services recruited an African American drumming instructor and a consultant who assisted youth in developing a play that traced African American music from the time of slavery to the present. Drumming, drama, music, art and dance - all of interest to the participating youth -- became the key activities of the program. In 2006, in response to budget reductions in city-funded services for youth, the eligibility for the program was opened to youth who resided in the community at no charge for participants. As the program continued to evolve, older youth began to express interest in participating, and activities were developed to respond to the interests of these youth.

\section{The Performing Arts Troupe: Goals and Key Structural Features}

The Performing Arts Troupe, in its current form, uses a youth development framework that integrates therapeutic approaches designed to address the impact of trauma on youth, promote resilience, and provide life skills training related to the developmental tasks of adolescence. Clinically, the program draws from Henry's (2005) "3-5-7 model" that identifies seven critical practice elements: engaging youth, listening to youth's words, speaking the truth, validating the youth's life story, creating a safe space, going back in time, and recognizing pain as part of the process. Within the context of that clinical framework, the program has four goals:

- Provide youth with opportunities through which they can address the effects of trauma in their lives;

- Promote youth resilience through experiential learning;

- Provide youth with life skills that they will utilize as they transition to adulthood; and

- Provide youth with opportunities to celebrate art and culture through diversity activities.

The Performing Arts Troupe draws on research that has documented the impact of trauma on adolescents' psychological and social functioning and the benefits of expressive therapies in addressing the impact of trauma. Based on this research, the Performing Arts Troupe provides a range of creative opportunities that complement and add to the benefits of cognitive and behaviorally oriented therapies. The program focuses on youth's strengths, which in the past may have been overshadowed by experiences of trauma and the behavioral and emotional problems sequelae of trauma. It provides youth with avenues to increase verbal and nonverbal expression and work through anger and disappointment associated with past losses and trauma. Through experiential learning, youth become able to recognize, appreciate, and more fully develop creative talents of which they may not have been aware.

Youth participants in the Performing Arts Troupe engage in skill-building and efficacy-enhancing activities. Through these activities, youth are able to strengthen their cognitive and selfregulating abilities in social settings and develop a positive self-concept, strong relationships with their peers, and a desire to act in ways that contribute to the welfare of the youth themselves, other youth and the group as a whole. Youth are provided with opportunities to "learn, voice, and demonstrate," tasks that Casey's direct practice with youth demonstrates to be normative to healthy adolescent development. Activities focus on strengthening youth's selfesteem, their ability to be self-directive and self-reliant, and their capacity to follow through with goals and plans. Importantly, activities offer youth opportunities to develop positive relationships with peers and adults. These relationships provide an interpersonal environment in which youth can develop trust, take risks in their relationships, and experience healthy separations. The social and emotional functioning skills learned are transferable to other areas of youth's lives. 


\section{Staffing}

Adult consultants from the community, three Casey Family Services social workers, a Casey Family Services supervisor, and a support person staff the Performing Arts Troupe. In addition, youth are recruited from the Casey's volunteer program to serve as "junior" consultants, providing youth with an opportunity to serve as leaders with other youth. The consultants and staff provide youth with the structure, guidance, praise, and recognition for their achievements that they may not have experienced with other adults in their lives.

The adult consultants are recruited through Casey's established community relationships. The following criteria guide the selection of these consultants:

- Understanding of the impact of trauma on youth

- A genuine desire to assist youth to achieve and develop

- A desire to contribute to the community

- An ability to create and sustain a structured and controlled environment

- An ability to relate effectively to youth and counteract the potential influence of negative social factors (drugs, gang involvement, and early sexual experience) on youth

- A history or characteristics similar to those of the youth served, which they have overcome

- An ability to articulate and demonstrate their experiences through practice or intervention

- Creativity and ability to think "outside the box"

- Compliance with requirements regarding criminal and child abuse background checks

\section{Budgeting}

The program has an operating budget of approximately $\$ 5,000$ for each session, which includes the costs of supplies, equipment, and food for youth at each meeting and an allocated portion of staff salaries. The per-youth cost is approximately $\$ 125$.

\section{The Population Served}

The Performing Arts Troupe program serves youth ages 9 to 18 who reside in the Bridgeport, Connecticut community or who are served through Casey Family Services' foster care or other service programs. Each semester, approximately 40 youth participate in the program. In the most recent Performing Arts Troupe session, 88 percent of the youth were referred by Casey Family Services (16 youth from the foster care program; seven youth who lived with their families and were served in other Casey Family Services programs). Table 1 provides the common characteristics of youth who participate in the program. 
Table 1

Characteristics of Youth Participants in the Performing Arts Troupe

\begin{tabular}{|c|c|c|}
\hline & Foster Youth & $\begin{array}{l}\text { Youth Living with } \\
\text { Families in the } \\
\text { Community }\end{array}$ \\
\hline \multirow[t]{2}{*}{ Family/Living Arrangements } & $\begin{array}{l}\text { Unrelated foster families, group } \\
\text { homes, and homes of relatives }\end{array}$ & $\begin{array}{l}\text { Single head of household } \\
\text { family structure }\end{array}$ \\
\hline & & $\begin{array}{l}\text { Low income families, with } \\
\text { many parents receiving } \\
\text { disability or welfare } \\
\text { benefits }\end{array}$ \\
\hline \multirow[t]{4}{*}{ Background Characteristics } & $\begin{array}{l}\text { History of sexual abuse, } \\
\text { physical abuse, and sexualized } \\
\text { behaviors }\end{array}$ & $\begin{array}{l}\text { History of or exposure to } \\
\text { domestic violence, } \\
\text { substance abuse, sexual } \\
\text { abuse, and/or physical } \\
\text { abuse }\end{array}$ \\
\hline & History of extensive loss & $\begin{array}{l}\text { Have experienced the } \\
\text { death of or the impending } \\
\text { death of birth parent or } \\
\text { sibling }\end{array}$ \\
\hline & $\begin{array}{l}\text { Multiple placements in foster } \\
\text { care }\end{array}$ & \\
\hline & $\begin{array}{l}\text { Involvement with mental health } \\
\text { services over a period of years }\end{array}$ & \\
\hline \multirow[t]{4}{*}{ Psychosocial Issues/Needs } & $\begin{array}{l}\text { Emotional and behavioral } \\
\text { difficulties as a result of past } \\
\text { trauma }\end{array}$ & $\begin{array}{l}\text { Struggling with academic } \\
\text { issues and special } \\
\text { education needs }\end{array}$ \\
\hline & $\begin{array}{l}\text { Struggling with academic issues } \\
\text { and special education needs }\end{array}$ & $\begin{array}{l}\text { Many struggling with } \\
\text { sexual identity issues }\end{array}$ \\
\hline & $\begin{array}{l}\text { Many struggling with sexual } \\
\text { identity issues }\end{array}$ & Low self-esteem \\
\hline & Low self-esteem & \\
\hline
\end{tabular}

The majority of youth who participate in the program are youth of color. In the most recent Performing Arts Troupe session, 73 percent of the youth were African American, 19 percent were Latino, one youth was white, and one youth self-identified as Portuguese. Youth of color, perhaps because of prior experiences with music and dance at their places of worship or elsewhere within their communities, have expressed high levels of interest in the Performing Arts Troupe since its inception. These experiences may make music, dance and art more accessible sources of healing for these youth than traditional psychotherapy.

Youth who participate in the Performing Arts Troupe may continue in the program in subsequent semesters if they desire, and many do so. In the most recent Performing Arts Troupe session, 61 percent of the participants had previously participated in the program. Youth who continue in the program report that the Performing Arts Troupe is a safe place to express themselves and a form of "group therapy" that they wish to continue over time. 
Recruitment of youth for the program takes place broadly through emails and flyers. The Casey Family Services life skills specialist actively promotes the program by providing information on activities, eligibility criteria for youth, the adult "consultants" who will work with the youth, the number of youth who can be accepted into the program, and time frames for referral. Referrals are made to the Performing Arts Troupe by Casey Family Services social workers and team leaders who work with youth in foster care and other Casey Family Services' programs, including the liaison for the Bridgeport community organization known as "Residents Addressing Community Concerns." The Casey Family Service Performing Arts Troupe team assesses each youth who is referred to the program. The youth's needs, in relation to his or her history of trauma, emotional stability, and current developmental competencies (social and emotional), are reviewed in light of the program's goals and structure. The team also considers each youth's:

- Desire to enhance his or her self-esteem, coping skills, communication skills, selfadvocacy, and leadership skills

- Motivation to learn new or enhance existing skills

- Strengths and needs in relation to peer connections and life skill development

- Ability to interact in a group structure with peers

- Ability to accept adult direction

- History of recent physical aggression (which will disqualify a youth from participation)

In addition, the team explores with the referring Casey Family Service social worker or other referring source the youth's current status at home, school, and the community and how the experience with the Performing Arts Troupe can both meet the youth's needs and enhance his or her strengths. Youth who state that they do not have creative expression skills or talents are not turned away and, in fact, are highly encouraged to apply.

\section{The Program Activities}

The Performing Arts Troupe is offered three times each year. In each session, activities typically include music, dance, drumming, and art. Youth provide Casey Family Services with information regarding the activities that they would like to have provided. Key to the selection of activities is that youth claim the activity as "theirs" and that the activity reflects "who they are," including their cultural identity. Youth are actively involved in planning and implementing each activity. The adult consultant or co-consultants provide direction and structure, facilitate the learning, and provide encouragement and support. Each youth selects the activity in which he or she will participate. Youth may participate in a single activity during the session or may rotate through several activities. Youth participate in the program 1.5 hours each week. Because the research and clinical literature suggest the therpeutic efficacy of writing, music, drumming and art, the Performing Arts Troupe has consistently offered these activities.

Writing and Performing Songs with Dance. In each session of the Performing Arts Troupe over the past two years, youth have jointly written a hip-hop song that they then record on a CD and perform, with choreographed dancing, at a community event. The program has found that the culture of hip-hop has been a motivating factor in youth's lives, and importantly, provides a conduit for youth to access their trauma and therapeutically rewrite and express emotions which they have been cognitively unable to do in formal therapy. Youth who participate in this activity are age 14 and older. 
In 2005, Casey Family Services developed a relationship with an African American music producer in Bridgeport who opened his studio to youth in the Performing Arts Troupe and mentored them in their production of the first song that the youth joined together to write. Fifteen youth, who called themselves "The Young Legends," wrote and produced the song, "Dreams." The introduction to "Dreams" reflects the deep experiences that the youth brought to the song:

"I have dreams to make it out of the ghetto From gun shots, bloody palms, addicts and all the negativity.

But my heart goes out to the people who will never

Come true even by bombs, by bullets

I will miss them, won't forget them.

The ones whose dreams were torn apart, With school books in my hands, dreams in my heart.

I will never let anyone tear my dreams apart."

In January 2006, while The Young Legends were perfecting "Dreams," the music producer and mentor to the youth was killed. The youth were deeply affected by his loss, and The Young Legends sang at the memorial service. Over a two-week period, the staff of the Performing Arts Troupe facilitated several therapeutic groups on funeral orientation, death, grief and loss, and honoring legacies with the youth and their families as they dealt with their feelings. The program offered the youth an opportunity to express their sadness, anger and grief, a process that many youth, despite many earlier losses, had not been afforded previously.

At this point in the evolution of the Performing Arts Troupe, staff added a clinical component involving group discussion. At the first meeting for each session, youth select the theme for the song that they will write. At each subsequent meeting, youth devote 45 minutes to a discussion of how the selected theme has impacted their lives and is currently affecting them. This process, facilitated by professional social workers and the adult consultants, allows youth to process the meaning of the theme with one another, exploring such issues as abandonment, loss, guilt and shame and more fully recognizing the power of music in the healing process.

Following the death of the producer/mentor, Casey Family Services recruited a new music producer from the community who supported the youth in writing a new song entitled "To the Top." This song includes the lyrics, "Stick to your dreams, don't ever stop; just keep believing, we'll make it to the top." In a recent Performing Arts Session (Fall 2006), youth completed "Dear Mom," a song/letter that examined the theme of youth's relationships with their birth mothers. Youth, with the support of the adult consultants, choreographed a dance to the lyrics of "Dear Mom," and performed the song at an agency holiday celebration. "Dreams," "To the Top," and "Dear Mom" illustrate the capacities of the participating youth to examine challenging issues in their lives.

In November 2006, a Casey Family Services consultant conducted a focus group with the youth who wrote and performed "Dear Mom." Several key themes arose in the discussion regarding their experience with the Performing Arts Troupe:

- Music is a healing tool, especially for youth who find it difficult to verbally express themselves.

- Joining with other youth is comforting and allows youth to be "themselves."

- The group is like a family - with ups and downs - and youth are attached to the "family."

- The group is fun. 
When asked whether participation in the Performing Arts Troupe had affected them personally, most youth said that it had. The key themes in this regard were that participation had given them greater confidence; provided them with a sense of belonging and with strong connections to other youth and the consultants; helped them in expressing their feelings and regulating their emotions, particularly anger and "attitude;" and helped them be more open to learning new things. Many youth expressed a sense of success that they had experienced, with newly discovered talents and abilities. There was uniform endorsement of the structure and opportunities provided by the Performing Arts Troupe.

Interviews also were conducted with the consultants for the music activity: two consultant music producers and the consultant choreographer. The consultants described many benefits of the program for the youth, commenting:

- "This program opens kids up. They can be with peers and get over their own problems with one another. They help one another."

- "Music grabs kids' attention. Music gives them the opportunity to develop life skills and music can change their lives."

- "We provide them with a way to cope with their troubles."

- "We help them stick with it and see what they can do."

- "The key is that the music is theirs - they write the songs, it is their words, and the songs mean so much to them."

The consultants also described the benefits of the program for themselves, commenting:

- "I love to see them grow. They will have these skills in the work world. It is a process - kids come in and say that they cannot sing and dance, and then they can't stop singing and dancing. Our positive energy feeds off of theirs and vice versa."

- "They give me more than I give them. I see the breakthroughs - I know that they will be okay if they have confrontations outside of the group. I want to be a small piece of their emotional growth, affecting their work ethic, their relationships, the way they run their lives."

Drumming. Drumming is offered to a younger group of youth, ages nine and older, who have experienced trauma in their lives. Drumming provides youth with social support and social networks, opportunities to deal with emotional trauma, and an understanding of and pride in their culture. Describing drumming "like the heart beat," the adult consultant strives to provide youth with a sense of self. Youth who often enter the activity uncertain of their ability to drum develop a sense of pride as they begin to participate and as they are helped to develop the ability to focus, listen, and follow through. The adult consultant commented in an interview:

"This makes me feel really good. I can see the pride in their faces, their excitement. It is a chance for them to express themselves without a lot of negative forces involved. They learn patterns, everything falls into place and only then do we focus on techniques. They walk away having accomplished something the first time they come."

The youth focus group confirmed the adult consultant's perceptions. When asked about their participation in drumming, youth said, "It makes me feel good," "It gives me a chance to 
shine," "It makes me feel more confident," and "I was scared at first but now I feel great, I feel nice. I can achieve something. I succeeded."

Art. The Performing Arts Troupe has offered art projects each year. Youth ages 8 to 17 years participated in the most recent project involving the use of watercolors, oils, metallics and glitter to develop art work based on fragrant frames, floating hearts, African masks, and royal king puzzles. The 20 participating youth had the freedom to choose the media they wished to use. After youth completed their art, a gallery opening, complete with a reception and servers, was held to display their work. The adult art consultant comments that youth often begin by saying, "I can't draw, but as they see their accomplishments, they develop a sense of pride and accomplishment."

\section{Preliminary Outcomes}

\section{Evaluation Results}

In December 2006, youth who had participated in the Fall 2006 Performing Arts Troupe were asked to complete written evaluation forms. Fourteen youth completed these evaluations, which asked them to rate items on a likert scale that ranged from 1 ("not at all") to 5 ("very much so"). Table 2 provides the percentage of youth who responded "very much so" on these items.

Table 2

Youth's Ratings of their Experiences with the Performing Arts Troupe

\begin{tabular}{|l|c|}
\hline \multicolumn{1}{|c|}{ Statement } & $\begin{array}{c}\text { Percent Stating } \\
\text { "Very much so" }\end{array}$ \\
\hline $\begin{array}{l}\text { I feel proud of my accomplishments in the Performing Arts } \\
\text { Troupe (PAT). }\end{array}$ & $100 \%$ \\
\hline By participating in PAT, I learned creativity and courage. & $86 \%$ \\
\hline $\begin{array}{l}\text { I enjoyed this expressive arts experience where I learned to } \\
\text { share my voice and story through music, drumming and dance. }\end{array}$ & $78 \%$ \\
\hline $\begin{array}{l}\text { This art and music expressive experience helped me become } \\
\text { comfortable with my peers. }\end{array}$ & $71 \%$ \\
\hline
\end{tabular}

Youth rated the adult consultants highly, with more than 50 percent rating the consultants as "very much so" on each characteristic provided. The largest percentage (71 percent) gave "very much so" ratings to the consultants' helping them "to strengthen and/or develop my existing skills." Sixty-four percent of the youth gave "very much so" ratings to the consultants' encouraging or empowering them when they lacked confidence. Other characteristics received "very much so" ratings at slightly lower levels: 57 percent of the youth gave "very much so" ratings to each of three characteristics of the consultants: consultants were respectful of youth's contributions, consultants made youth feel comfortable in showing the areas that needed improvement, and consultants showed patience when youth were frustrated.

\section{Youth's Stories}

Jamal

Jamal is a 16-year-old African-American male who, because of a very difficult history of abandonment and childhood trauma, found it hard to develop trusting relationships. He typically 
isolated himself and had very little interaction with peers or adults. As a result of his participation in the Performing Arts Troupe and the support that he experienced from his peers and the adult consultants, Jamal began to engage with others, proactively reaching out to peers and seeking help from adults. He now exhibits a new level of confidence and self-esteem. The Performing Arts Troupe provided him with skills that strengthened his ability to become actively involved with the "permanency team" that is working with him to identify a new permanent family for him. Jamal specifically requested that a youth leader peer with the Performing Arts Troupe be a member of his permanency team. With this support, Jamal took the lead in identifying a new family with whom he could live while in foster care. That family has completed Pre-Service Training, and Jamal will move to their home at the end of the school year.

Jamal has joined the Casey Family Services Youth Advocacy Group and now regularly speaks with local legislators and representatives of the public child welfare agency about the needs of youth in care and the improvements that are needed in foster care. With the opportunities that he has had to act as a leader in the Performing Arts Troupe, Jamal feels confident that he can obtain a job. He reports that his self expression through music has helped him cope with the recent disclosure of his biological parent's struggles with health issues. The skills gained through the Performing Arts Troupe have prepared him to deal with the trauma of his past and emotionally express "where he has been" through the creation of a life book that tells his story.

\section{Cassandra}

Seventeen-year-old Cassandra has been participating in the Performance Arts Troupe for the last year and half. When she became involved with the program, she was having difficulties with her peers. In these relationships, she was either overbearing and aggressive, or reclusive and timid. She had difficulty developing healthy, long lasting friendships. Since her involvement in the program, Cassandra has developed a new calmness and strength. She recently handled a verbal altercation with equanimity, withdrawing to calm herself and then returning with an apology and an explanation as to why she was upset. Her growing sense of self confidence since joining the program played a key role in Cassandra's recent acceptance into a national program for youth in foster care preparing to make a successful transition to adulthood. She is now enrolled in cosmetology training and has access to money-matching opportunities through the national program's individual development account.

Cassandra is viewed as a leader by her Performing Arts Troupe peers. She is an active member of the Casey Family Services Youth Planning Committee for the program. She has strengthened her self-advocacy skills, even seeking out the Casey Family Services division director to request a change in her placement. Since her involvement with the Performing Arts Troupe, Cassandra become more vocal in the permanency planning decisions that are being made in connection with her new resource family. Cassandra speaks of her participation in the program with great pride. Cassandra has stated that the program has given her an opportunity to appear cool and be a leader at the same time.

\section{Donald}

Donald has participated in the Performing Arts Troupe for four years. Through joining a group of his peers with similar life experiences, he found a non-threatening peer group in which he was able to grow and creatively express some of the traumatic events of his life in his own words. Hip-hop, as a popular cultural means of expression, has allowed him to articulate his and others' life events. Because Donald is intellectually gifted and creative and loves to use and play with words, he quickly engaged and developed a deep ownership in the music. He was 
able to say, "Yes, this is me!" This year, at age 17, Donald was asked to serve as a "youth leader." He has demonstrated a strong ability to lead his peers and has become a peer mentor for a youth who is participating in the program. In conjunction with his leadership role with the Performing Arts Troupe, Donald has become involved in advocacy activities on behalf of youth in foster care, meeting with state child welfare leaders and traveling to Washington, DC to present at a major child welfare conference. Since participating in the Performing Arts Troupe, Donald has improved his grades and obtained a job, surprising some of the adults in his life who believed that he lacked the maturity to achieve these goals. Donald now states that he would like to attend college, in marked contrast to his pre-Performing Arts Troupe desire to simply complete an independent living program.

\section{Enrique}

Enrique, age 15, has grown with his participation in the Performing Arts Troupe. Prior to joining the program, he was extremely shy, had difficulty engaging with peers, and was often bullied by them. Since joining the program, Enrique has developed a sense of self-confidence and social skills. Through the program, he has become comfortable expressing his views and actively contributing his ideas. In a group discussion, he was able to "stand alone" in recommending a theme for the group's song, a theme that others did not readily support. Using the skills he developed through the Performing Arts Troupe, Enrique agreed to be a member of a planning committee for the agency's "Camper Corps" weekend. He created and facilitated a very successful workshop about healthy relationships. His peers now view him as a leader and their respect for him has deepened. Last summer, Enrique participated in a summer job program.

Enrique has benefited from a supportive environment in which he can discuss his history. He verbalizes surprise and excitement when he realizes that aspects of his history in foster care are similar to those of the other group members. Enrique actively participated in writing song lyrics to help him cope with the loss that he has felt from not being parented by his biological mother and father. He has included his lyrics in his lifebook, which contains a legacy of memories, experiences, and relationships that symbolize significant people in his life. He has used the lyrics to ask his mother and father difficult questions about why they were unable to care for him.

\section{Amanda}

Initially, Amanda, now age 16, wondered if she made the right decision to participate in the Performing Arts Troupe program. Although she enjoyed the social experience, she felt that she could not learn the drumming and dance routines as easily as her peers. Through participating in the program, however, Amanda began to recognize that she has benefited in many ways: She has learned about working as a member of a team, and she has had many opportunities to explore her interests and take risks. She has taken greater responsibility for her own behavior, such as cutting school. She is now able to self-report her truancy, discuss why she cut school, and connect her behavior to her feelings.

Amanda has established connections with other youth and strengthened her interpersonal shills, an area that has always been a challenge for her. With the death of the Performing Arts Troupe mentor, she has focused specifically on building relationships with others. Her connection with other youth has motivated her to participate in other Casey Family Services activities. Using leadership skills that she developed through the Performing Arts Troupe, Amanda served as the chairperson, workshop developer, and facilitator for the agency's Camper Corps weekend. She 
obtained employment through the agency's summer employment program, at which she learned job skills and connected with a volunteer who continues to visit with her.

\section{Conclusion}

The Performing Arts Troupe program at Casey Family Services has proven to be an effective approach to engaging youth in creative expression activities that address trauma, promote resilience, and provide youth with opportunities to develop core competencies that will support their successful transitions to adulthood. This cost-effective, community-based program addresses a range of youth's needs and strengthens youth's competencies.

The agency's experience in developing and implementing the Performing Arts Troupe indicates that certain elements are essential to the success of this type of program: the commitment and enthusiasm of agency staff; strong connections with community organizations through which youth in the community are referred; the ability to identify and engage community leaders who can effectively serve as adult consultants; and active engagement of youth as peer leaders and participants. The Performing Arts Troupe offers a programmatic approach that can be replicated in other communities, with modifications as appropriate to best meet the needs and cultural interests of the youth served.

\section{Acknowledgement:}

The authors wish to acknowledge Betty Whooten-McElveen, Casey Family Services Life Skills Specialist, for her outstanding commitment in contributing to the development and success of the Performing Arts Troupe and, more importantly, for nurturing and cultivating the innate skills of the youth served by Casey Family Services.

\section{References}

Abramson, L.Y., Metalsky, G.I., \& Alloy, L.B. (1989). Hopelessness depression: A theory-based subtype of depression. Psychological Review, 96, 358-372.

Abramson, L.Y., Seligman, M.E., \& Teasdale, J. (1978). Learned helplessness in humans: Critique and reformulation. Journal of Abnormal Psychology, 87, 49-74.

Allen, D.M., \& Tarnowski, K.J. (1989). Depressive characteristics of physically abused children. Journal of Abnormal Psychology, 17, 1-11.

Anderson, T. (2005). PTSD in children and adolescents. Chicago, IL: University of Chicago, The Great Cities Institute.

Armsworth, M.W., \& Holaday, M. (1993). The effects of psychological trauma on children and adolescents. Journal of Counseling and Development, 72, 49-56.

Arnett, J.J. (2000). Emerging adulthood: A theory of the development from the late teens through the twenties. American Psychologist, 55, 469-480.

Arnett, J.J. (2001). Conceptions of the transition to adulthood: Perspectives from adolescence to midlife. Journal of Adult Development, 8, 133-143. 
Avrahami, D. (2006). Visual art therapy's unique contribution in the treatment of post-traumatic stress disorder. Journal of Trauma \& Dissociation, 6(4), 5j-38.

Bolland, J.M. (2003). Hopelessness and risk behavior among adolescents living in high-poverty inner-city neighbourhoods. Journal of Adolescence, 26(2), 145-158.

Buckner, J.C., Beardslee, W.R., \& Bassuk, E.L. (2004). Exposure to violence and low-income children's mental health: Direct, moderated, and mediated relations. American Journal of Orthopsychiatry, 74, 413-423.

Bussiere, A., Pokempner, J., \& Troia, J. (2005). Adolescents, the foster care system, and the transition to adulthood: What legal aid lawyers need to know. Clearinghouse REVIEW Journal of Poverty Law and Policy, July-August, 62-78.

Carrion, V., Weems, C., Ray, R., \& Reiss, A. (2002). Toward an empirical definition of PTSD: The phenomenology of PTSD symptoms in youth. American Academy of Children and Adolescent Psychiatry, 41(2), 166-173.

Cobb, S. (1976). Social support as a moderator of life stress. Psychosomatic Medicine, 38, 300314.

Cook, A., Blaustein, M., Spinazzola, J., \& van der Kolk, B. (Eds). (2003). Complex trauma in children and adolescents. Washington, DC: US Department of Health and Human Services, National Child Traumatic Stress Network.

Cook, A., Spinazzola, J., Ford, J., Lanktree, C., et al. (2005). Complex trauma in children and adolescents. Psychiatric Anals, 35(5), 390-398.

Garber, J., Keiley, M., \& Martin, N. (2002). Developmental trajectories of adolescents' depressive symptoms: Predictors of change. Journal of Consulting and Clinical Psychology, 70, 79-95.

Ge, X., Lorenz, F., Conger, R., \& Elder, G. (1994). Trajectories of stressful life events and depressive symptoms during adolescence. Developmental Psychology, 30, 467-483.

Harber, K.D., \& Pennebaker, J.W. (1992). Overcoming traumatic memories. In S.A. Christianson (Ed.), The handbook of emotion and memory: Research and theory (pp. 359-387). Hillsdale, NUJ: Lawrence Erlbaum.

Henry, D. (2005). The 3-5-7 model: Preparing children for permanency. Accessed April 6, 2007: http://humanservices.ucdavis.edu/academy/pdf/The357model.pdf.

Joiner, T.E., \& Wagner, K.D. (1995). Attributional style and depression in children and adolescents: A meta-analytic review. Clinical Psychology Review, 15, 777-798.

Kaduson, H.G., \& Schaefer, C.E. (Eds.) (2001). 101 more favorite play therapy techniques. Northvale, NJ: Jason Aronson. 
Kimball, C., \& Golding, J. (2004). Adolescent maltreatment: An overview of the research. The Prevention Researcher, 11(1), 18-31.

Klorer, P.G. (2005). Expressive therapy with severely maltreated children: Neuroscience contributions. Art therapy: Journal of the American Art Therapy Association, 22(4), 213-220.

Lorion, R.P., \& Saltzman, W. (1993). Children's exposure to community violence: Following a path from concern to research to action. Psychiatry, 56, 55-65.

Luthar, S.S., Cicchetti, D., \& Becker, B. (2000). The construct of resilience: A critical evaluation and guidelines for future work. Child Development, 71, 543-562.

Masten, A.S. (2001). Ordinary magic: Resilience processes in development. American Psychologist, 56, 227-238.

Masten, A.S., Best, K.M., \& Garmezy, N. (1990). Resilience and development: Contributions from the study of children who overcome adversity. Developmental Psychopathology, 2, 425444.

Masten, A.S., \& Coatsworth, J. (1998). The development of competence I favorable and unfavorable environments: Lesson from research of successful children. American Psychologist, 53, 205-220.

Massinga, R., \& Pecora, P.J. (2004). Providing better opportunities for older children in the child welfare system. Future of Children, 14, 151-173.

National Child Traumatic Stress Network. (2003). Complex trauma in children and adolescents. Allston, MA: Author.

Pennefaker, J.W., Colder, M., \& Sharp, L.K. (1990). Accelerating the coping process. Journal of Personality \& Social Psychology, 58, 528-537.

Pennebaker, J.W., \& Francis, M.E. (1996). Cognitive, emotional and language processes in disclosure. Cognition \& Emotion, 10, 601-626.

Pizarro, J. (2004). The efficacy of art and writing therapy: Increasing positive mental health outcomes and participant retention after exposure to traumatic experience. Art Therapy: The Journal of the American Art Therapy Association, 21(1), 5-12.

Reynolds, M.W., Nabors, L., \& Quinlan, A. (2000). The effectiveness of art therapy: Does it work? Art Therapy: The Journal of the American Art Therapy Association, 17, 207-213.

Rubin, J. (1999). Art therapy: An introduction. Philadelphia, PA: Brunner/Mazel.

Smythe, J.M. (1998). Written emotional expression: Effect sizes, outcomes types, and moderating variables. Journal of Consulting and Clinical Psychology, 66, 174-184.

Werner, A.A., \& Smith, A.E. (1992). High risk children from birth to adulthood. Ithaca, NY: Cornell University Press. 
Winkleman, M. (2003). Complementary therapy for addiction: "Drumming out drugs." American Journal of Public Health, 93(4), 647-651.

Wyman, P.A., Sandler, I., Wolchik, S., \& Nelson, K. (2000). Resilience as cumulative competence promotion and stress protection: Theory and intervention. In D. Cicchetti \& J. Rappaport (Eds.), The promotion of wellness in children and adolescents (pp. 133-184). Washington, DC Child Welfare League of America.

Yamaguchi, T. (1997). Hiroshima atomic bomb survivors: Group arts therapy approaches. In R. Rebollo Pratt \& Y. Tokuda (Eds.), Arts medicine (pp. 53-57). Benton Harbor, MI: Patterson Printing.

(C) Copyright of Journal of Youth Development $~$ Bridging Research and Practice. Content may not be copied or emailed to multiple sites or posted to a listserv without copyright holder's express written permission. However, users may print, download or email articles for individual use. 